\title{
Prolyl hydroxylase in the skin of patients with obstructive jaundice
}

\author{
THAN THAN, J. O'D. MCGEE' 1 , AND L. H. BLUMGART \\ From the University Departments of Surgery and Pathology, Glasgow Royal Infirmary and the \\ Department of Pathology ${ }^{1}$, Radcliffe Infirmary, Oxford, UK
}

SUMMARY Prolyl hydroxylase was estimated in the skin of 24 jaundiced patients and 25 nonjaundiced patients. The activity of this enzyme was markedly reduced in the skin of the jaundiced patients.

It has long been the impression of surgeons that wound healing is impaired in patients with obstructive jaundice, particularly when this is associated with malignant disease (Torrance, 1972). However, there is no conclusive evidence to support this belief although it has been shown experimentally that migration of fibroblasts and granuloma formation are abnormal in rats with obstructive jaundice (Lee, 1972). More recently, Ellis and his colleagues (Bayer and Ellis, 1976) have suggested that wound healing is defective in jaundiced rats.

In a preliminary communication (Than Than et al., 1974), we reported that prolyl hydroxylase, which catalyses the synthesis of hydroxyproline in collagen, was markedly reduced in the skin of a small group of patients with obstructive jaundice. This paper reports a more extended study of skin prolyl hydroxylase activity in three groups of patients with obstructive jaundice.

\section{Material and methods}

MEASUREMENT OF SKIN PROLYL HYDROXYLASE

Skin prolyl hydroxylase was measured as previously reported (Than Than et al., 1974). After informed consent had been obtained a specimen of skin was taken either from the edge of an upper midline or right upper paramedian incision at the time of operation or, in patients not submitted to laparotomy, at the site of a needle biopsy of the liver. Fat was carefully removed from the skin specimen which was then wrapped in aluminium foil and stored for assay at $-20^{\circ} \mathrm{C}$. Assays for prolyl hydroxylase were carried out in three batches of patients, and for each batch substrate was prepared by a modification of the

Received for publication 31 March 1977 method of Hutton et al. (1966). The efficiency of the substrate prepared differed from batch to batch, and the results of the assays are therefore not comparable between batches. At the time of assay approximately $0.5 \mathrm{~g}$ of skin was homogenised, as previously described (Than Than et al., 1974), the homogenates being centrifuged at $20000 \mathrm{~g}$ for 15 minutes for the first two batches of patients and at $15000 \mathrm{~g}$ for 15 minutes for the third batch. Prolyl hydroxylase activity was measured in duplicate by the tritium release technique (Hutton et al., 1966) in a modified reaction mixture (McGee et al., 1974). Proteins in the skin supernatants were estimated by the method of Lowry et al. (1951). Prolyl hydroxylase levels are expressed as counts per minute per milligram of protein.

PATIENTS

Patients in all three batches consisted of those with jaundice consequent on benign or malignant obstruction of the common bile duct or as a result of alcoholic or primary biliary cirrhosis. Control studies were carried out in non-jaundiced patients submitted to laparotomy for surgical treatment of peptic ulcer or gall bladder disease, and in one patient for aneurysm of the abdominal aorta.

Plasma proteins, serum bilirubin, serum aspartate aminotransferase (SGOT), serum alanine aminotransferase (SGPT), and alkaline phosphatase were measured by routine laboratory methods.

\section{STATISTICAL ANALYSIS}

Since a fairly wide scatter of results with a correspondingly large standard deviation has been found in our studies of skin prolyl hydroxylase and since the results do not display a normal distribution the Mann-Whitney non-parametric test with Wilcoxon's U-statistics (Campbell, 1974) was used to analyse the 1044 
results. This test compares possible low values (in this case low levels of serum prolyl hydroxylase in jaundiced patients) with all possible combinations of higher values in control subjects.

\section{Results}

The median value for skin prolyl hydroxylase activity in the jaundiced patients was markedly lower than that of the controls in all three batches of patients (Tables 1, 2, and 3). Indeed, in batches 2 and 3 prolyl hydroxylase activity was approximately $50 \%$ of that of the control group whereas in batch 2 (Table 2) it was only one-third of that of the control. Statistical analysis, however, revealed that there was a significant difference between the jaundiced and control groups only in series 2 and 3 , series 1 failing to reach statistical significance. There was no detectable difference in prolyl hydroxylase activity between patients jaundiced as the result of bile duct obstruction or as a result of liver disease, and there appeared to be no difference either between patients with benign or malignant obstruction of the common bile duct.

Table 1 Skin prolyl hydroxylase $(\mathrm{PH})$ activities in control and jaundiced patients (series 1$)$

\begin{tabular}{|c|c|c|c|c|c|}
\hline Group & No. & Age & Diagnosis & $\begin{array}{l}\text { Skin } P H \\
(\text { cpm/mg protein) }\end{array}$ & Median \\
\hline Controls & $\begin{array}{l}1 \\
2 \\
3 \\
4\end{array}$ & $\begin{array}{l}45 \\
68 \\
59 \\
56\end{array}$ & $\begin{array}{c}\text { Peptic ulcer } \\
\text { " " " } \\
\text { " } "\end{array}$ & $\begin{array}{l}113 \\
113 \\
527 \\
888\end{array}$ & 320 \\
\hline Obstructive jaundice & $\begin{array}{l}1 \\
2 \\
3 \\
4 \\
5 \\
6\end{array}$ & $\begin{array}{l}69 \\
73 \\
55 \\
69 \\
78 \\
74\end{array}$ & $\begin{array}{l}\text { Carcinoma head of pancreas } \\
\text { Gall stones } \\
\text { Cholecystitis } \\
\text { Gall stones } \\
\text { Gall stones + chronic cholecystitis } \\
\text { Carcinoma head of pancreas }\end{array}$ & $\begin{array}{r}24 \\
103 \\
116 \\
187 \\
333 \\
464\end{array}$ & $151 \cdot 1$ \\
\hline Alcoholic cirrhosis & $\begin{array}{l}1 \\
2\end{array}$ & $\begin{array}{l}50 \\
58\end{array}$ & $\begin{array}{l}\text { Acute alcoholic liver disease } \\
\text { Alcoholic cirrhosis }\end{array}$ & $\begin{array}{l}116 \\
206\end{array}$ & 161 \\
\hline Primary biliary cirrhosis & $\begin{array}{l}1 \\
2 \\
3\end{array}$ & $\begin{array}{l}58 \\
54 \\
44\end{array}$ & PBC & $\begin{array}{l}128 \\
166 \\
225\end{array}$ & 166 \\
\hline
\end{tabular}

Each prolyl hydroxylase result represents the mean of two estimations.

Table 2 Skin prolyl hydroxylase $(\mathrm{PH})$ activities in control and jaundiced patients (series 2)

\begin{tabular}{|c|c|c|c|c|c|}
\hline Group & No. & Age & Diagnosis & $\begin{array}{l}\text { Skin } P H \\
(\text { cpm/mg protein) }\end{array}$ & Median \\
\hline Controls & $\begin{array}{r}1 \\
2 \\
3 \\
4 \\
5 \\
6 \\
7 \\
8 \\
9 \\
10 \\
11 \\
12 \\
13 \\
14 \\
15\end{array}$ & $\begin{array}{l}23 \\
57 \\
42 \\
19 \\
39 \\
81 \\
\\
53 \\
45 \\
31 \\
35 \\
42\end{array}$ & $\begin{array}{l}\text { Chronic cholecystitis } \\
\text { Peptic ulcer } \\
\text { Gall stones } \\
\text { Peptic ulcer } \\
\text { Gall stones } \\
\text { Chronic cholecystitis } \\
\text { Call stones } \\
\text { Peptic ulcer } \\
\text { Chronic cholecystitis } \\
\text { Gall stones } \\
\text { Chronic cholecystitis } \\
\text { Peptic ulcer } \\
\text { Chronic pyloric ulcer }\end{array}$ & $\begin{array}{r}76 \\
104 \\
153 \\
161 \\
197 \\
259 \\
259 \\
365 \\
421 \\
538 \\
581 \\
731 \\
936 \\
1169 \\
1340\end{array}$ & 365 \\
\hline Obstructive jaundice & $\begin{array}{r}1 \\
2 \\
3 \\
4 \\
5 \\
6 \\
7 \\
8 \\
9 \\
10\end{array}$ & $\begin{array}{l}22 \\
75 \\
\\
31 \\
54 \\
49 \\
37 \\
70 \\
82 \\
61\end{array}$ & $\begin{array}{l}\text { Choledochal cyst } \\
\text { Gall stones } \\
\text { Carcinoma pancreas } \\
\text { Secondaries in hepatic nodes } \\
\text { Gall stones } \\
\text { Acholangitis } \\
\text { Carcinoma common bile duct } \\
\text { Gall stones " " " } \\
\text { Carcinoma common bile duct }\end{array}$ & $\begin{array}{r}16 \\
25 \\
43 \\
64 \\
111 \\
131 \\
150 \\
493 \\
530 \\
558\end{array}$ & 121 \\
\hline
\end{tabular}

Each prolyl hydroxylase result represents the mean of two estimations. 
Table 3 Skin prolyl hydroxylase $(P H)$ activities in control and jaundiced patients (series 3)

\begin{tabular}{|c|c|c|c|c|c|}
\hline Group & No. & Age & Diagnosis & $\begin{array}{l}\text { Skin } P H \\
(\mathrm{cpm} / \mathrm{mg} \text { protein })\end{array}$ & Median \\
\hline Controls & $\begin{array}{l}1 \\
2 \\
3 \\
4 \\
5 \\
6\end{array}$ & $\begin{array}{l}55 \\
25 \\
21 \\
55 \\
\\
69\end{array}$ & $\begin{array}{l}\text { Aortic aneurysm } \\
\text { Duodenal ulcer } \\
\text { Gall stones } \\
\text { Duodenal ulcer } \\
\text { Jejunal ulcer } \\
\text { Gall stones }\end{array}$ & $\begin{array}{l}38 \\
39 \\
50 \\
51 \\
52 \\
69\end{array}$ & $50 \cdot 5$ \\
\hline Jaundice & $\begin{array}{l}1 \\
2 \\
3\end{array}$ & $\begin{array}{l}65 \\
36 \\
60\end{array}$ & $\begin{array}{l}\text { Gall stones } \\
\text { Carcinoma head of pancreas }\end{array}$ & $\begin{array}{l}21 \\
22 \\
36\end{array}$ & 22 \\
\hline
\end{tabular}

Each prolyl hydroxylase result represents the mean of two estimations.

The total protein contents in the skin supernatants of both jaundiced and control patients were not different from each other and only four of the total of 24 jaundiced patients had a serum albumin level below $3 \mathrm{~g} / 100 \mathrm{ml}$. No correlation was found between serum bilirubin level, serum albumin level, SGOT, SGPT or alkaline phosphatase and the level of the skin prolyl hydroxylase.

\section{Discussion}

The findings we report are in accord with the results of our preliminary report (Than Than et al., 1974), namely, that there is a reduction in prolyl hydroxylase in the skin of jaundiced patients. Prolyl hydroxylase is responsible for the synthesis of hydroxyproline in collagen and hydroxyproline stabilises the collagen triple helix (Jiminez et al., 1973). A reduction in skin level of this enzyme in jaundice could conceivably lead to a diminution in the stability of skin collagen. On the other hand, it may be that collagen synthesis is generally depressed and that the low levels of prolyl hydroxylase are an index of this. Either defect in collagen synthesis might account for the clinical impression of poor wound healing in jaundiced patients.

It should be remembered, however, that biliary obstruction may be associated with a degree of nutritional deficiency and often with biliary tract infection, and these factors must be taken into account. It is, however, interesting to note that only four of the 24 jaundiced patients studied had a serum albumin level below $3 \mathrm{~g} / 100 \mathrm{ml}$. Moreover, no correlation could be demonstrated between the serum albumin level and the decrease in the prolyl hydroxylase activity in the jaundiced patient.

It is interesting to note that the serum bilirubin level could not be correlated with the decrease in prolyl hydroxylase activity. It seems unlikely that bilirubin itself would have an effect in lowering the prolyl hydroxylase activity and indeed we have found that sera containing high levels of added bilirubin had no effect in lowering the prolyl hydroxylase activity in vivo (Than Than et al., in preparation). It is possible that a local action of retained bile salts might be responsible but we have no evidence of this at present.

The evidence we present suggests that jaundice is associated with low skin prolyl hydroxylase, and in patients submitted to operation for obstructive jaundice this might impair healing. A controlled clinical study would, however, be necessary to prove this point. In this respect it is interesting that our animal experiments (Than Than et al., in preparation, Than Than 1976) demonstrate decreased prolyl hydroxylase activity in the skin of jaundiced rats and that this can be correlated with the tensile strength of the wounds in such animals. These observations accord with those of Lee (1972), who demonstrated delay in the migration of fibroblasts and granuloma formation in rats with obstructive jaundice, and those of Bayer and Ellis (1976) which demonstrated delayed wound healing in gastric incisions and parietal peritoneal defects in jaundiced rats.

\section{References}

Bayer, I., and Ellis, H. (1976). Jaundice and wound healing: an experimental study. British Journal of Surgery, 63, 392-396.

Campbell, R. C. (1974). Statistics for Biologists, 2nd edition, pp. 59-61. Cambridge University Press, London.

Hutton, J. J., Jr., Tappel, A. L., and Udenfriend, S. (1966). A rapid assay for collagen proline hydroxylase. Analytical Biochemistry, 16, 384-394.

Jiminez, S., Harsch, M., and Rosenbloom, J. (1973). 
Hydroxyproline stabilizes the triple helix of chick tendon collagen. Biochemical and Biophysical Research Communications, 52, 106-114.

Lee, E. (1972). The effect of obstructive jaundice on the migration of reticulo-endothelial cells and fibroblasts into early experimental granulomata. British Journal of Surgery, 59, 875-877.

Lowry, O. H., Rosebrough, N. J., Farr, A. L., and Randall, R. J. (1951). Protein measurement with the Folin phenol reagent. Journal of Biological Chemistry, 193, 265-275.
McGee, J. O'D., Patrick, R. S., Rodger, M. C., and Luty, C. M. (1974). Collagen proline hydroxylase activity and ${ }^{35} \mathrm{~S}$ sulphate uptake in human liver biopsies. Gut, 15. 260-267.

Than Than (1976). Skin prolyl hydroxylase and tensiometry in jaundice. Thesis, University of Glasgow.

Than Than, McGee, J. O'D., Sokhi, G. S., Patrick, R. S., and Blumgart, L. H. (1974). Skin prolyl hydroxylase in patients with obstructive jaundice. Lancet, 2, 807-808.

Torrance, H. B. (1972). In International Symposium on Sutures in Wound Repair, p. 41.

\section{The October 1977 Issue}

\section{THE OCTOBER 1977 ISSUE CONTAINS THE FOLLOWING PAPERS}

Feulgen microdensitometry and analysis of S-phase cells in cervical tumour biopsies B. DIXON AND R. H. STEAD

IgA localisation in glomerular diseases W. LAWLER, GEORGE WILLIAMS, P. TARPEY, E. JOAN ACHESON, AND N. P. MALLICK

Occurrence of $\mathrm{e}$ antigen in acute hepatitis $\mathrm{B}$ PATRICIA E. GIBSON AND KOKILA RUPARELIA

Pregnancy and antibody to factor VIII JENNIFER VOKE AND ELIZABETH LETSKY

Interrelationship of Chlamydia trachomatis and other pathogens in the female genital tract G. L. RIDGWAY AND J. D. ORIEL

Streptococcus milleri in the appendix PAULINE M. POOLE AND GEORGE WILSON

Klebsiella: Taxonomy, nomenclature, and communication J. G. BARR

Incidence of $\mathrm{K} 1$ antigen in Escherichia coli isolated from blood and cerebrospinal fluid of patients in the United Kingdom T. CHEASTY, R. J. GROSS, AND B. ROWE

Astrovirus associated gastroenteritis in a children's ward J. B. KURTZ, T. W. LEE, AND D. PICKERING

Prolonged erythrocyte T-polyagglutination in two children with bowel disorders DAISY OBEID, G. W. G. BIRD, AND JUNE WINGHAM
Formaldehyde induced anti-N: a possible cause of renal graft failure D. W. GORST, R. A. RICHES, AND P. H. RENTON

Effect of renal transplantation on marrow mast cell hyperplasia of chronic renal failure H. A. ELLIS, KATHLEEN M. PEART, AND A. M. PIERIDES

Parathyroid carcinoma in familial hyperparathyroidism J. S. DINNEN, R. H. GREENWOOD, J. H. JONES, D. A. WALKER, AND E. D. WILLIAMS

Dermatitis herpetiformis: a comparative assessment of skin and bowel abnormality T. COONEY, C. T. DOYLE, D. BUCKLEY, AND M. J. WHELTON

Surface marker and other characteristics of Gaucher's cells G. F. BURNS, J. C. CAWLEY, R. J. FLEMENS, K. E. HIGGY, C. P. WORMAN, C. R. BARKER, B. E. ROBERTS, AND F. G. J. HAYHOE

\section{Technical methods}

A 'dip-slide' method of sampling bacteria for measuring the efficacy of antiseptics used in labour M. R. WEBSTER

Identification of non-sporing anaerobic bacteria D. A. LEIGH AND K. SIMMONS

Virus titrations using trypsin modified erythrocytes K. F. SHORTRIDGE AND L. Y. HU

Book reviews

Copies are still available and may be obtained from the PUBLISHING MANAGER, BRITISH MEDICAL ASSOCIATION, TAVISTOCK SQUARE, LONDON, WC1H 9JR, price $£ 3.00$, including postage 